His numerous restored figures of the fishes he described are especially important, combining artistic style with the most minute accuracy, and left incomplete wherever there is the least doubt as to structure. Both in writing and in drawing, indeed, he always aimed at such precision that his publications were often delayed for a long period by hesitation, and his correspondents were accustomed to regard his dilatory methods with impatience. Even so unique a fossil as the Lower Devonian Palæospondylus was in his possession upwards of ten years before he ventured upon its description, and he only published an account of it when specimens seemed likely to fall into less competent hands. Dr. Traquair was, in fact, a genuine student, anxious only to make sure of the truth, and a large circle of friends will mourn the loss of one whose kindly spirit endeared him to all who came in close contact with him.

Dr. Traquair was elected a fellow of the Royal Society in I88I, and received the honorary degree of LL.D. from the University of Edinburgh in 1893. He was awarded the MacDougall-Brisbane medal of the Royal Society of Edinburgh, and also the Lyell medal of the Geological Society of London, in rgor, and a Royal medal of the Royal Society of London in 1907. A list of his writings and an excellent portrait of him accompany a biographical notice published in The Geological Magazine for June, I909.

A. S. W.

\section{W. F. KIRBY.}

$\mathrm{W}$ ILLAM FORSELL KIRBY, whose death on November 20 we regret to announce, was the eldest of the five sons of Samuel Kirby, banker, of High Street, Leicester. He was born at Leicester, January 14,1844 . When a boy of seven Kirby was taken to London, and saw the British Museum and Gould's collection of humming birds, and, while still very young, when the family moved to a house two or three miles from Leicester, his mother suggested that he should collect butterflies, and thus aroused his first interest in entomology.

Kirby was privately educated by tutors. He always believed that exclusion from the life and experiences of a public school was a permanent disadvantage to him.

Samuel Kirby died in 1854 , and the family moved to Burgess Hill and to Brighton (I 857-60). Kirby, although still quite a boy, joined the Brighton and Sussex Natural History Society, and began to publish notes in The Entomologist's Weekly Intelligencer. He went to London in 1860 , joined the Entomological Society in $186 r$, and soon became acquainted with all its leading members-with Westwood, Hewitson, Stainton, Knaggs, and Perceval Wright. In I866 he married Johanna Maria Kappel, daughter of J. W. Kappel, of Hilden, near Düsseldorf. Their only child, now W. Egmont Kirby, M.D., was born in 1867 . Mrs. Kirby interested herself in all her husband's work, helping him in every possible way, and her death in 1903 darkened the last years of his life.

From 1867 to 1879 Kirby was an assistant in NO. 2248, VOL. 90] the museum of the Royal Dublin Society, afterwards the National Museum of Science and Art. On the death of Frederick Smith, in 1879, he moved to London, and entered the zoological department of the British Museum.

It is impossible on the present occasion to do more than allude to the series of volumes by which W. F. Kirby helped to stimulate and spread an interest in natural history. Among the numerous works which he wrote for the student of insect systematics special mention must be made of the "Synonymic Catalogue of Diurnal Lepidoptera" (187I). Few books have done more for their subject than this careful and accurate work, which was suggested to the author by the sight of $\mathrm{H}$. W. Bates's MS. lists.

Between 1869 and 1884 Kirby wrote the reports on Lepidoptera, and later on the greater part of the insects for the "Zoological Record"-a work for which he was specially qualified by his wide knowledge of languages. Kirby's publications also deal with Scandinavian and Finnish folklore, a subject which deeply interested him. He was for a time one of the hon. secretaries of the Entomological Society, and was honoured by foreign scientific societies. He was ever ready to put his great knowledge at the disposal of other workers.

\section{E. B. P.}

\section{NOTES.}

THE anniversary meeting of the Royal Society for the election of council and officers will be held on Saturday next, November $3^{\circ}$, at $40^{\prime}$ 'clock p.m. There will be no meeting of the society to-day.

Full particulars of the meeting, held at the Mansion House on October 23 last, to consider the whole question of the proposed memorial to Lord Lister were given in an article in the issue of NATURE for October $3 x$ (vol. xc., p. 254). The meeting unanimously decided that the most suitable form of memorial would be :(I) A tablet with medallion and inscription in Westminster Abbey; (2) the erection of a monument in a public place in London; (3) the establishment of an International Lister Memorial Fund for the advancement of surgery, from which either grants in aid of researches bearing on surgery, or awards in recognition of distinguished contributions to surgical science, should be made, irrespective of nationality. To carry out these proposals a large sum of money will be required, and the executive committee is appealing for donations to all persons who wish to pay a tribute to the memory of a great man of science and a great surgeon. Before the issue of this appeal subscriptions had been received amounting to something like 27ool., and we notice that the first list of donations includes 5ool. each from Lord Iveagh and Mr. W. F. D. Smith, 25ol. from Mr. Otto Beit, roo guineas each from Lord Northcliffe and Sir James Whitehead, Bart., and rool. each from the Duke of Bedford, K.G., Sir Ernest Cassell, G.C.B., Sir W. Watson Cheyne, Bart., F.R.S., and Lord Rothschild, G.C.V.O. It is proposed to form committees in the provinces, in the dependencies of the Empire, and in 